This is an author produced version of a paper published in Molecular Immunology. This paper has been peer-reviewed but does not include the final publisher proof-corrections or journal pagination.

Citation for the published paper:

Mark L, Lee WH, Spiller OB, Villoutreix BO, Blom AM.

"The Kaposi's sarcoma-associated herpesvirus complement control protein (KCP) binds to heparin and cell surfaces via positively charged amino acids in CCP1-2."

Molecular Immunology, 2006, Issue: Jan 25.

http://dx.doi.org/10.1016/j.molimm.2005.09.016

Access to the published version may require journal subscription. Published with permission from: Elsevier 


\title{
The Kaposi's sarcoma-associated human herpesvirus complement control protein (KCP) binds to heparin and cell surfaces via positively charged amino acids in CCP 1-2.
}

\author{
Linda Mark ${ }^{\mathrm{ae}}$, Wen H. Lee ${ }^{\mathrm{bde}}$, O. Brad Spiller ${ }^{\mathrm{c}}$, Bruno O. Villoutreix ${ }^{\mathrm{b}}$ and Anna M. Blom ${ }^{\mathrm{a} *}$ \\ a Department of Laboratory Medicine, Lund University, University Hospital Malmö, Malmö S-20502, Sweden, \\ ${ }^{\mathrm{b}}$ INSERM U648, University of Paris V, Paris 75006, FRANCE, \\ ${ }^{c}$ Department of Medical Biochemistry and Immunology, School of Medicine, Cardiff University, Heath Park, \\ Cardiff CF14 4XN, United Kingdom \\ ${ }^{\mathrm{d} P r e s e n t}$ address: University of Oxford, Structural Genomics Consortium, Botnar Research Center, Oxford OX3 \\ 7LD, United Kingdom. \\ ethese authors contributed equally to the study
}

*Corresponding author: Anna M. Blom, U-MAS, Wallenberg laboratory, entrance $46,6^{\text {th }}$ floor, S-20502, Malmö, SWEDEN, telephone: +46-(0)40-338233 fax: +46-(0)40-337044, e-mail: anna.blom@med.lu.se

\begin{abstract}
The Kaposi's sarcoma-associated herpesvirus (KSHV) complement control protein (KCP) inhibits the human complement system, and is similar in structure and function to endogenous complement inhibitors. Other inhibitors such as $\mathrm{C} 4 \mathrm{~b}$-binding protein and factor $\mathrm{H}$, as well as the viral homologue vaccinia virus complement control protein are known to bind heparin and, for the two latter, also to glycosaminoglycans at the surface of cells. We report here that KCP also binds to heparin at physiological ionic strength. With help of site directed mutagenesis, positively charged amino acids in the two N-terminal complement control protein (CCP) domains 1-2 were found to be necessary for heparin binding. In silico molecular docking of heparin to KCP confirmed the experimental data, and further explored the heparin binding site, enabling us to present a model of the KCP-heparin interaction. Furthermore, the docking analysis also yielded insights of the KCP structure, by indicating that the angle between $\mathrm{CCP}$ domains 1-2 during the initial binding of heparin is more extended than in the model we have previously presented. We also found that KCP binds to heparan sulfate and weakly to glycosaminoglycans at the surface of cells. This might indicate that KCP at the surface of viral particles aids in the primary attachment to the target cells, which is known to involve binding to heparan sulfate. Therefore, the present study contributes to the knowledge of heparin-protein interactions in general as well as to the understanding of the biology of KSHV.
\end{abstract}

\footnotetext{
Abbreviations: KSHV: Kaposi's sarcoma-associated herpesvirus, KCP: KSHV complement control protein, RCA: regulator of complement activation, CCP: complement control protein domain, C4BP: C4b-binding protein VCP: vaccinia virus complement control protein, DAF: decay accelerating factor, CR1: complement receptor 1
} 


\section{Introduction}

KSHV is the most recently discovered human herpesvirus. It has been found to cause Kaposi's sarcoma (Chang et al., 1994) primary effusion lymphoma (Cesarman et al., 1995) and Castleman's disease (Soulier et al., 1995). KSHV has a broad cellular tropism. In vivo, KSHV DNA has been found in B-cells (Cesarman et al., 1995), endothelial cells, (Boshoff et al., 1995), keratinocytes (Foreman et al.) and monocytes (Monini et al., 1999). In vitro, KSHV can infect a variety of human cells; e.g. endothelial cells (Panyutich et al., 1998), fibroblasts (Akula et al., 2003; Vieira et al., 2001) and keratinocytes (Cerimele et al., 2001) as well as several cell lines from different species, e.g. CHO cells (Bechtel et al., 2003).

KSHV attachment to its target cells involves binding to heparan sulfate (Akula et al., 2001b; Birkmann et al., 2001), in accordance with the observation that binding to heparan sulfate is a common initial step of cell entry for many of the human herpes viruses (reviewed in (Shukla and Spear, 2001; Spear and Longnecker, 2003). Heparan sulfate is a ubiquitously expressed glycosaminoglycan, present at the surface of cells via covalent binding to a cell membrane attached core protein. Heparan sulfate is similar in structure to the soluble glycosaminoglycan heparin, which is why heparin binding often is interpreted as an indication of heparan sulfate binding. The KSHV encoded glycoprotein $\mathrm{gB}$ and gpK8.1 have been identified as heparan sulfate binding proteins on the KSHV lipid envelope (Akula et al., 2001a; Birkmann et al., 2001; Wang et al., 2001). gB also binds to the host cell integrin $\alpha 3 \beta 1$ via its RGD sequence, which induces intracellular signalling (Akula et al., 2002; Naranatt et al., 2003). Endocytosis following the initial attachment has been observed as entry mechanism for the KSHV particle (Akula et al., 2003; Akula et al., 2001b).

The focus of this study is the protein encoded by the fourth open reading frame of $\mathrm{KSHV}$; KCP. KCP is a homologue to the proteins of the human gene family called RCA. The RCA proteins are soluble or membrane bound and they inhibit the complement system by disrupting the $\mathrm{C} 3$ convertases, (either the classical or the alternative $\mathrm{C} 3$ convertase), which are the key enzyme complexes formed during the complement activation cascade. KCP inhibits the $\mathrm{C} 3$ convertases in two distinct manners; i) decay acceleration of the classical $\mathrm{C} 3$ convertase and ii) cofactor activity for factor I, that in the presence of $\mathrm{KCP}$ can cleave $\mathrm{C} 3 \mathrm{~b}$ and $\mathrm{C} 4 \mathrm{~b}$, which are parts of the alternative and the classical C3 convertase, respectively (Mullick et al., 2003; Spiller, 2003; Spiller et al., 2003).

KCP is expressed during the lytic phase (Jenner et al., 2001), and has been detected at the surface of KSHV infected pleural effusion lymphoma cells upon induction of lytic replication (Spiller et al., 2003). It is thus likely that KCP is present on the subsequently formed KSHV particles. Hence, it is probable that KCP protects KSHV particles and infected cells from eradication by the complement system.

Structurally, KCP resembles the human RCAs. It contains four extracellular CCP and it is attached to the cell surface by a transmembrane spanning region. There are three splice variants of KCP, which differ in the region between the CCP domains and the transmembrane region (Spiller et al., 2003). We have recently engineered a wide range of site-directed KCP mutants and analysis of their function confirmed that the molecular mechanisms used by KCP strongly resemble those used by human complement inhibitors (Mark et al., 2004). Some of the human RCAs; factor $\mathrm{H}$ and C4BP, bind to heparin, which is essential for their biological function. Another viral RCA homologue, VCP, has also been shown to bind to heparin and to the surface of cells (Smith et al., 2000; Smith et al., 2003).

The aim of this study was to investigate whether KCP is capable of binding to proteoglycans as heparin, given its structural similarity to factor H and C4BP. Such an interaction could be of biological significance: it would indicate that KCP aids in the attachment of viral particles to its target cells. 


\section{Materials and Methods}

\subsection{Cells}

CHO-K1 cells were purchased from American Type Culture Collection (Manassas, USA) or received as a kind gift from Dr Dick Heinegård (Lund University, Sweden). CHO pgsA-745 cells, which are deficient in xylosyltransferase and do not produce glycosaminoglycans, (Esko et al., 1985) were received from Dr Dick Heinegård. The cells were propagated in F-12K Nutrient Mixture (Kaighn's Modification, GIBCO-Invitrogen, Carlsbad, USA) supplemented with 10\% fetal calf serum and $50 \mathrm{U} / \mathrm{ml}$ pencillin and $50 \mu \mathrm{g} / \mathrm{ml}$ streptavidin.

\subsection{Proteins}

Recombinant wild type KCP and the KCP point mutants were produced as described previously (Mark et al., 2004). Briefly, the DNA encoding wild type or mutated KCP (the signal peptide, the four CCP domains and the following 48 amino acids) was cloned into a eukaryotic expression vector, which yields a fusion protein with the addition of an in-frame C-terminal human IgG1 Fc region (described in (Harris et al., 2000)). The resulting soluble and dimeric proteins were expressed in $\mathrm{CHO}$ cells and purified from the cell supernatant by affinity chromatography using protein A-sepharose (GE Healthcare, Fairfield, USA). The dimeric form of $\mathrm{KCP}$ is used for all experiments, unless otherwise indicated. A KCP-Fc dimeric construct without CCP 4 (called KCP delCCP4) was produced in a similar manner, using forward primer 5'-TCTAGAGCTAGCATGGCCTTTTTAAGACAAAC and reverse primer 5'GCGGCCGCAGCTGCTGTATGGGTGTCTTCA to amplify the DNA encoding CCP1 to CCP3 of wild type KCP. The DNA was cleaved by XbaI and NotI (in bold) prior to ligation into the same expression vector as for the wild type and point mutants.

Monomeric KCP without the Fc-tail, was generated by cleavage with $\mathrm{fXa}$. Cleavage was performed at room temperature for 12 hours, using 0.5 units of factor Xa (R\&D systems, Minneapolis, MN USA) per $\mu \mathrm{g}$ of KCP. Human plasma Factor I, (Crossley and Porter, 1980) C3 (Andersson et al., 1991) and C4 (Andersson et al., 1991) were purified from plasma as previously described. To create $\mathrm{C} 4$ met and $\mathrm{C} 3$ met, $\mathrm{C} 4$ and $\mathrm{C} 3$ were treated with methylamine to hydrolyze the internal thioester bond; proteins were incubated with $100 \mathrm{mM}$ methylamine $\mathrm{pH} 8$ 8.5 , at $37^{\circ} \mathrm{C}$ for $1 \mathrm{~h}$, followed by dialysis in $50 \mathrm{mM}$ Tris- $\mathrm{HCl}, \mathrm{pH} 7.5$ and $150 \mathrm{mM} \mathrm{NaCl}$ or 10 $\mathrm{mM}$ Hepes-KOH, pH 7.4 supplemented with $50 \mathrm{mM} \mathrm{NaCl}$ and $0.005 \%$ tween 20 . For simplicity, $\mathrm{C} 4 \mathrm{met}$ and $\mathrm{C} 3 \mathrm{met}$ are referred to as $\mathrm{C} 4 \mathrm{~b}$ and $\mathrm{C} 3 \mathrm{~b}$ in the text. For radioactive $\mathrm{C} 3 \mathrm{~b}$ and $\mathrm{C} 4 \mathrm{~b}$, proteins purchased from Advanced Research Technologies (San Diego, USA) were used. They were iodinated with ${ }^{125} \mathrm{I}$ using the chloramine T method (Greenwood et al., 1963).

\section{$2.3 \mathrm{C} 3 \mathrm{~b} / \mathrm{C} 4 \mathrm{~b}$ degradation assay}

For cleavage of $\mathrm{C} 3 \mathrm{~b}$ and $\mathrm{C} 4 \mathrm{~b}$ by factor I, $\mathrm{KCP}(0.3 \mu \mathrm{M})$ was incubated with $375 \mathrm{nM} \mathrm{C} 3 \mathrm{~b}$ or 125 $\mathrm{nM} \mathrm{C4b}, 60 \mathrm{nM}$ factor I and trace amounts of ${ }^{125} \mathrm{I}$ labeled C3b/C4b in $50 \mu \mathrm{l}$ of $50 \mathrm{mM}$ Tris-HCl, $150 \mathrm{mM} \mathrm{NaCl}, \mathrm{pH}$ 7.4. A sample without factor I was used as a negative control. The samples were incubated at $37^{\circ} \mathrm{C}$ for $1.5 \mathrm{~h}$ prior to separation by SDS-PAGE (10-15\% gradient) under reducing conditions. The radiolabelled $\mathrm{C} 3 \mathrm{~b}$ or $\mathrm{C} 4 \mathrm{~b}$ was visualized by autoradiography using Phosphoimaging analysis (GE Health care, Fairfield, USA). Cleavage products were quantified by densitometry. Heparin blocking of the reaction was achieved by preincubation of KCP with low molecular weight heparin Fragmin (stock $25000 \mathrm{IU} / \mathrm{ml}(156.2 \mathrm{mg} / \mathrm{ml})$ Pfizer, New York, USA) for $30 \mathrm{~min}$ at room temperature before starting the cleavage reaction. The concentration of Fragmin in the final cleavage reactions ranged from 0 to $31 \mathrm{mg} / \mathrm{ml}$. $1 \mathrm{mg}$ Fragmin corresponds to $160 \mathrm{IU}$. Heparin blocking was also performed by full length heparin, using soluble Heparin (Lövens, Ballerup, Denmark) or Heparin Sodium salt (ICN Biomedicals, Irvine, USA) with similar results (data not shown). Also heparan sulfate (heparan sulfate sodium salt from bovine kidney, Sigma) was used to inhibit cofactor function. 


\subsection{Surface Plasmon Resonance (Biacore)}

The inhibition of the KCP binding to $\mathrm{C} 4 \mathrm{~b}$ mediated by heparin was studied by surface plasmon resonance (Biacore, Uppsala, Sweden). The flow cells of a CM5 sensor chip were activated with $20 \mu 1$ of $0.2 \mathrm{M}$ 1-ethyl-3-(3 dimethylaminopropyl) carbodiimide with $0.05 \mathrm{M}$ N-hydroxysulfosuccimide at a flow rate of $5 \mu \mathrm{l} / \mathrm{min}$, and then $\mathrm{KCP}(0.02 \mathrm{mg} / \mathrm{ml}$ in $10 \mathrm{mM}$ sodium acetate $)$ was injected over flow cell 3 to reach 3996 resonance units. Unreacted groups were blocked with $20 \mu \mathrm{l}$ of $1 \mathrm{M}$ ethanolamine, $\mathrm{pH}$ 8.5. Flow cell 1 was activated and subsequently blocked, to be used as negative control. Various concentrations of $\mathrm{C} 4 \mathrm{~b}$ together with various concentrations of the low molecular weight heparin Fragmin (Pfizer) were injected over the sensor chip. The protein solutions were injected for $200 \mathrm{~s}$ to achieve saturation during the association phase at a constant flow rate of $30 \mu \mathrm{l} / \mathrm{min}$. The sample was injected first over the negative control surface and then over the immobilized KCP flow cell and analyzed for a dissociation phase of $200 \mathrm{~s}$ at the same flow rate. Between each different protein sample injected, the flow cell surfaces were regenerated with a $25 \mu \mathrm{l}$ injection of $2 \mathrm{M} \mathrm{NaCl}$ to remove bound ligands. The obtained sensorgrams were analyzed using the BiaEvaluation 3.0 software. Signals were normalized by subtracting the nonspecific signal measured by control flow cell 1 . $\mathrm{K}_{\mathrm{D}}$ for $\mathrm{C} 4 \mathrm{~b}$ binding to $\mathrm{KCP}$ was calculated for each different concentration of Fragmin.

\subsection{Binding to heparin column}

A $5 \mathrm{ml}$ Heparin HiTrap column (GE Health care) was connected to an ÄKTA explorer (FPLC system) (GE Health care) and equilibrated with $20 \mathrm{mM}$ Tris-HCl, $\mathrm{pH}$ 7.4. Approximately 110 $\mu \mathrm{g}$ of wild type or mutated $\mathrm{KCP}$ was added at a flow rate of $4 \mathrm{ml} / \mathrm{min}$, followed by washing with $10 \mathrm{ml}$ equilibration buffer. Bound protein was then eluted with a $50 \mathrm{ml}$ gradient of $0-0.5 \mathrm{M}$ $\mathrm{NaCl}$ in equilibration buffer. Protein elution was detected by measurement of absorbance at 214 $\mathrm{nm}$ and the $\mathrm{NaCl}$ concentration at the elution peak was calculated using the conductivity values measured by the ÄKTA system.

\subsection{ELISA}

Heparan sulfate sodium salt from bovine kidney (Sigma Aldrich, St Louis, USA), and chondroitin sulfate A sodium salt from bovine trachea (Sigma Aldrich) were dissolved in coating buffer ( $75 \mathrm{mM} \mathrm{Na}$-carbonate, $\mathrm{pH} 9.6$ ) to a concentration of $100 \mu \mathrm{g} / \mathrm{ml}$ and added to MAXIsorp mirotiter plates for incubation at $4^{\circ} \mathrm{C}$ over night. Free sites in the wells were blocked by incubation with quench ( $3 \%$ fish gelatin, $10 \mathrm{mM}$ Tris $\mathrm{HCl}, 75 \mathrm{mM} \mathrm{NaCl}, 0.05 \%$ Tween 20 , $\mathrm{pH}$ 8.0) at room temperature for $1 \mathrm{~h}$. KCP was dissolved in quench and allowed to bind to the proteoglycans for $2 \mathrm{~h}$ at room temperature, followed by incubation for $1 \mathrm{~h}$ in room temperature with horse radish peroxidase conjugated polyclonal antibodies from rabbit directed against human IgG, diluted 1:1000 in quench (DAKO, Glostrup, Denmark). Between each incubation step, the microtiter wells were washed with $10 \mathrm{mM}$ Tris $\mathrm{HCl}, 75 \mathrm{mM} \mathrm{NaCl}, 0.05 \%$ Tween 20 , $\mathrm{pH}$ 8.0. Bound antibodies were detected using OPD (Orthophenylene diamine) tablets (Dako) dissolved in $\mathrm{H}_{2} \mathrm{O}$ supplemented with $\mathrm{H}_{2} \mathrm{O}_{2}$, For biotinylated heparin and heparan sulfate, the microtiter plates were coated with $10 \mu \mathrm{g} / \mathrm{ml}$ streptavidin. After blocking, as above, biotinylated heparin and heparan sulfate were allowed to bind at a concentration of $10 \mu \mathrm{g} / \mathrm{ml}$ for $1 \mathrm{~h}$, at RT.The rest of the ELISA was performed as above. Biotinylation was carried out as follows; Heparan sulfate from bovine kidney or Heparin were dissolved in $0.1 \mathrm{M}$ morpholinoethanesulfonic acid, $\mathrm{pH} 5.6$, to a concentration of $2.5 \mathrm{mg} / \mathrm{ml}$. To $200 \mu \mathrm{l}$ of the heparin/heparan sulfate solution, $10 \mu \mathrm{l}$ freshly prepared $10 \mathrm{mM} \mathrm{N}$-ethyl$\mathrm{N}$ '(dimethylpropyl)carbodiimideand was added, as well as $10 \mu \mathrm{l}$ freshly prepared $50 \mathrm{mM}$ Biotin-hydrazide (Pierce, Rockford, USA), dissolved in DMSO. This mixture was incubated for $6 \mathrm{~h}$ at room temperature, with shaking. The biotinylated glycosaminoglycans were desalted and 
separated from unbound Biotin-hydrazide by chromatography using a PD-10 column (GE Health care), equilibrated with $\mathrm{H}_{2} 0$. Biotinylated_proteoglycans were freeze-dried and dissolved in $0.3 \mathrm{M} \mathrm{NaCl}$.

\subsection{Flow cytometric studies of KCP binding to cell surface}

CHO-cells (CHO-K1 or pgsA-745) were detached from their culturing flask by Versene (GIBCO-Invitrogen) to ensure cell surface protein integrity. The cells were spun down and dissolved in VB-sucrose-BSA buffer (1.02 g/L Na-5,5-diethylbarbiturate, $1 \mathrm{mM} \mathrm{MgCl}_{2}, 0.15$ $\mathrm{mM} \mathrm{CaCl} 2,280 \mathrm{mM}$ sucrose and $0.2 \%$ BSA). Approximately 25000 cells were incubated with various amounts of FITC-labelled wild type or mutated KCP, for $90 \mathrm{~min}$ at room temperature with moderate shaking, in a total volume of $20 \mu \mathrm{l}$. Blocking of binding was performed with various amounts of heparin (Heparin Sodium, ICN Biomedicals). To investigate the binding as a function of the ionic strength, the $\mathrm{NaCl}$ concentration was adjusted by mixing low ionic strength VB-sucrose-BSA buffer with high ionic strength VBS (1.02 g/L Na-5,5-diethylbarbiturate, $1 \mathrm{mM}$ $\mathrm{MgCl}_{2}, 0.15 \mathrm{mM} \mathrm{CaCl}_{2}, 284 \mathrm{mM} \mathrm{NaCl}$ and $0.2 \% \mathrm{BSA}$ ) in adequate proportions. After $\mathrm{KCP}$ incubation, the cells were washed twice with the incubation buffer and placed on ice. KCP binding was then measured using a Becton Dickinson FACSort flow cytometer (BD Biosciences, Franklin Lake, USA).

\subsection{FITC-labeling of proteins}

$\mathrm{KCP}$ was dialysed against $1 \mathrm{M} \mathrm{NaHCO}, \mathrm{pH}$ 9. For labelling, $5 \mu$ FITC (Sigma-Aldrich) (10 $\mu \mathrm{g} / \mathrm{ml}$ in DMSO) was added to $500 \mu \mathrm{l}$ protein. Labelling was allowed for $2 \mathrm{~h}$ at room temperature, in the dark. The labelling was stopped by addition of $50 \mu 11 \mathrm{M} \mathrm{NH}_{4} \mathrm{Cl}(\mathrm{pH} 7)$ to $500 \mu 1$ FITC-protein solution. FITC labelled protein was separated from unbound FITC molecules by separation on a PD-10 column (GE Healthcare). KCP-FITC was then dialysed against VB-sucrose buffer (1.02 g/L Na-5,5-diethylbarbiturate, $1 \mathrm{mM} \mathrm{MgCl}, 0.15 \mathrm{mM} \mathrm{CaCl}_{2}$, $280 \mathrm{mM}$ sucrose). Protein concentration was measured by photospectroscopy at $280 \mathrm{~nm}$.

\subsection{In silico docking of Heparin to the KCP model}

A homology model of KCP has been built using the crystallographic structure of VCP (PDB code $1 \mathrm{~g} 40$, resolution $2.2 \AA$ ) and the angle between CCP1 and 2 was remodelled according to the angle presented by the corresponding domains of CR1 (PDB code 1gkn NMR) and DAF (PDB code 1ok3 resolution $2.2 \AA$ ), as previously described (Lukacik et al., 2004; Mark et al., 2004; Murthy et al., 2001; Smith et al., 2002). The inter-domain loops and its vicinities were manually remodelled and submitted to local energy minimization as implemented in the program ICM (http://www.molsoft.com/) to resolve clashes and optimize local interactions. The resulting extended model was converted to internal coordinates via an ICM routine and submitted to the protein-small ligand docking protocol of ICM-Pro (reviewed by Brive and Abagyan (Brive and Abagyan, 2002)) with modifications (see below) in order to investigate possible orientation of heparin at the surface of KCP. As control, the KCP model presenting a 'bent' conformation directly derived from the VCP structure was also submitted to the same docking protocol. To abbreviate calculation time of docking simulations the CCP1 and CCP2 domains of each KCP models (extended and bent forms) were represented by a series of energy grid potentials that are approximations of the proteins' properties. Five different properties were taken into account, namely van der Waals potential (with carbon and hydrogen probes), electrostatic potential, hydrogen bonding potential and hydrophobic potential (Fernandez-Recio et al., 2002; Totrov, 2001) The heparin molecule (PDB code 1hpn) (Mulloy et al., 1993) was represented explicitly (all-atoms) and full flexibility was allowed during the docking around the rotatable bonds. The Merck Molecular Force Field parameters were assigned to atoms of both the KCP models and heparin. The first docking step involved sampling different positions and 
orientations of the heparin molecule with respect to $\mathrm{CCP} 1$ and 2 of $\mathrm{KCP}$ using a pseudoBrownian Monte Carlo (Fernandez-Recio et al., 2002) procedure without providing additional information from the mutation study. Random heparin torsion angles were also changed in this step and local energy minimization was performed immediately after to solve local steric clashes and energy strains. Thus, new combinations of heparin internal geometry, its position and orientation (hereafter called a 'pose') were generated after every Monte Carlo move and each new pose was selected according to the Metropolis criterion. The interaction energy of a heparin pose with each of the five energy grid potentials were calculated through an unifying energy function (Brive and Abagyan, 2002; Totrov and Abagyan, 1997) and the final energy value of every pose were recorded. The energy of every new pose is then compared to the ones obtained in previous iterations and ranked accordingly. We kept only the 20 best ranked poses (called a 'stack') and a new pose was only recorded in the stack if it presented an interaction energy better than those already stored in the stack file. If the root mean square deviation for all nonhydrogen atoms of the new pose was below $5.5 \AA$ of an existing pose already stored in the conformational stack file, it was recorded as an additional 'occurrence' (number of visits to the same pose) rather than added as a new pose. For statistically reliable results, we performed a total of 14 million Monte Carlo steps.

Since the initial docking of heparin was performed into an approximated representation (grid potentials) of the receptor, further refinement of the best poses was carried out where the regions of the protein interacting with the heparin (the interface area) and the heparin molecule itself were computed explicitly (i.e., the system is now flexible from the protein side and partially flexible from the heparin side). The best heparin poses were allowed restricted changes in their geometry and position (in agreement to observation of X-ray protein structure-co-crystallized with heparin), while side-chains of the KCP residues in the vicinities were also allowed to vary in order to improve the networking and geometry of hydrogen bonds involved in the binding, as published elsewhere (Fernandez-Recio et al., 2003). This refinement step was carried out until convergence using a Monte Carlo methodology similar to the one used in the docking step, with the Metropolis criterion for acceptance of new solutions.

\section{Results}

\subsection{KCP binds heparin}

For the experiments throughout this study, unless otherwise indicated, we used a recombinant, dimeric, soluble KCP-Fc protein that was produced as previously described (Mark et al., 2004). This protein contains the $4 \mathrm{CCP}$ domains of KCP, followed by a 48 amino acid spacer region (also from $\mathrm{KCP}$ ) and a C-terminal human $\mathrm{IgG}_{1} \mathrm{Fc}$-tail, used for purification of the protein. Fig. 1 shows a Coomassie staining of the wild type KCP and the five KCP point mutants assessed for heparin binding in fig. 2, displaying their purity and that the mutants migrate with the same velocity as wild type KCP in the gel. To study the direct binding to heparin, KCP was injected onto a Heparin column. Injection was performed at $0 \mathrm{mM} \mathrm{NaCl}$ and bound $\mathrm{KCP}$ was eluted with a gradient of increasing ionic strength, ranging from $0-500 \mathrm{mM} \mathrm{NaCl}$. KCP bound to heparin under physiological conditions, and lost its affinity for heparin at around $200 \mathrm{mM} \mathrm{NaCl}$ (fig. 2A). To localise the heparin binding site, we also tested the heparin binding of KCP point mutants where positively charged amino acids (one to three amino acids per mutant) had been altered to glutamine or alanine (Mark et al., 2004). Mutants Arg20Gln/Arg33Gln/Arg35Gln and Lys64Gln/Lys65 Gln/Lys88Gln were severely or totally defective in heparin binding (2B-C). However, mutants Lys131Gln/Lys133Gln/His135Gln, Arg136Gln/Lys138Gln and His158Ala/His171Ala/His213Ala bound heparin with the same efficiency as wild type KCP (2D-F). Thereby, the heparin binding can be localized to a positive stretch in the most Nterminal part of KCP, CCP 1-2. Single point mutants, Lys64Gln, Lys65Gln and Lys88Gln, were 
used to evaluate the contribution to heparin binding of one individual amino acid. These single point mutants each bound to heparin more efficiently than the corresponding triple mutant, indicating an additive effect of the mutations. Mutation of amino acid Lys65 had the greatest effect on heparin binding of these three Lys residues. CCP4 was not involved in heparin binding, as studied with a KCP CCP4 deletion construct, which bound to heparin with even higher apparent affinity compared to wild type KCP. To determine if the dimeric form of KCP influenced the heparin binding, a monomeric KCP form was generated. Binding of the monomeric KCP to heparin sepharose was found to be slightly decreased, suggesting an additive effect between the two binding sites in the dimeric form, i.e. they were both available for heparin binding.

\subsection{Molecular docking of heparin to KCP}

To further investigate the heparin binding site in KCP, we performed in silico molecular docking, where heparin was docked to a theoretical structure of KCP CCP1-2. Modelling of the KCP structure was originally described in (Mark et al., 2004), where VCP was used as a template. This first model of KCP inherited from VCP a bent conformation in the arrangement of CCP1 and CCP2. However, the overall bent conformation of VCP (1g40) may have been induced by crystallographic packing effects. Therefore, we remodelled the angle between CCP1 and 2 to a more extended conformation (see Materials and methods), as seen in CR1 and DAF. The immediate result from the remodelling of the CCP1 and 2 domains angle is the alignment of the basic residues that have been mutated in the present study. In the extended conformation, the KCP model presents a more extensive positive patch than in its bent conformation, where the amino acids pointed to be critical for heparin binding are located near the inter-domain hinge. The results of the molecular docking simulations are presented in fig. 3 and the residues predicted to form hydrogen bonds to the heparin molecule are listed in table 1. For definition of vocabulary specific to docking experiments, see materials and methods. We observed that the docking solutions agreeing with the experiments were more frequent in the extended than in the bent conformation. In the extended conformation simulations, the most energetically favourable heparin pose was placed in contact with 5 out of 6 critical amino acids identified by mutagenesis (fig. 3A,C, table 1). Moreover, it was also the pose that accumulated the highest number of visits (408 occurrences) during the simulation. On the other hand, the best solution of the bent conformation simulation that agrees with mutagenesis data utilised only 3 out of the 6 critical amino acids. Not only this was not the most energetically favourable conformation but also the number of occurrences of this pose was only 24 . These results suggest that the 3D structure of the bent conformation is less likely to efficiently bind heparin and that to be in agreement with both the computed binding energies and the site directed mutagenesis, the extended conformation of $\mathrm{KCP}$ is required. The inset on fig. $3 \mathrm{C}$ presents a close-up view of the hinge between CCP1-2 in its extended conformation, demonstrating its similarity to corresponding angles in DAF and CR1.

\subsection{Heparin inhibits binding of $C 4 b$ and interferes with KCP cofactor function}

$\mathrm{KCP}$ is a cofactor for factor I mediated cleavage of $\mathrm{C} 3 \mathrm{~b}$ and $\mathrm{C} 4 \mathrm{~b}$. In a previous study, we showed that the positive amino acids Lys64, Lys65 and Lys88 are important for both C4b cleavage and C3b cleavage and that the positive patch composed of Arg20, Arg33 and Arg35 is involved in $\mathrm{C} 4 \mathrm{~b}$ cleavage. Therefore, if heparin binds to these amino acids, it is probable that the cofactor function would be inhibited. This was assessed in a cofactor assay, in which factor I was allowed to cleave $\mathrm{C} 3 \mathrm{~b}$ and $\mathrm{C} 4 \mathrm{~b}$ in the presence of $\mathrm{KCP}$ and various concentrations of heparin (fig. 4). The cofactor function was inhibited by heparin, in a dose dependent manner. The cleavage products were reduced to $50 \%$ at $3.1 \mathrm{mg} / \mathrm{ml}$ heparin, for both $\mathrm{C} 3 \mathrm{~b}$ and $\mathrm{C} 4 \mathrm{~b}$ cleavage. This corresponds to around 3000 heparin molecules per KCP dimer. We verified that 
the inhibition of cofactor function was specific, as addition of the carrier buffer, in the absence of heparin, did not affect the $\mathrm{C} 4 \mathrm{~b}$ or $\mathrm{C} 3 \mathrm{~b}$ cleavage by KCP (data not shown). We also tested other forms of heparin (see materials and methods), which inhibited KCP cofactor function in a similar manner (data not shown). The cofactor function of KCP necessitates binding to $\mathrm{C} 4 \mathrm{~b} / \mathrm{C} 3 \mathrm{~b}$, thereby making these molecules susceptible for factor I cleavage. The disrupted cofactor function thus indicates that heparin binds to the same site on $\mathrm{KCP}$ as $\mathrm{C} 3 \mathrm{~b}$ and $\mathrm{C} 4 \mathrm{~b}$. To verify this, the influence of heparin on the direct binding of $\mathrm{C} 4 \mathrm{~b}$ to KCP was studied using the surface plasmon resonance technique (Biacore). KCP was coupled to a CM5 sensor chip and various concentrations of $\mathrm{C} 4 \mathrm{~b}$ together with various amounts of heparin were allowed to bind. Heparin inhibited the binding of $\mathrm{C} 4 \mathrm{~b}$ to $\mathrm{KCP}$. The $\mathrm{K}_{\mathrm{D}}$ for $\mathrm{C} 4 \mathrm{~b}$ binding to $\mathrm{KCP}$ at the various concentrations of heparin is presented in table $2.0 .03 \mathrm{mg} / \mathrm{ml}$ of heparin had no effect on $\mathrm{C} 4 \mathrm{~b}$ binding to $\mathrm{KCP}$, while $0.3 \mathrm{mg} / \mathrm{ml}$ and $1.6 \mathrm{mg} / \mathrm{ml}$ decreased the binding of $\mathrm{C} 4 \mathrm{~b}$ to $\mathrm{KCP}$ by eightfold and 260-fold, respectively.

\section{$3.4 \mathrm{KCP}$ binds to heparan sulfate}

Since heparin is structurally similar to heparan sulfate, and chondroitin sulfate, we wanted to investigate if KCP could also bind these proteoglycans. An ELISA was performed, where KCP was allowed to bind to microtiter wells coated with either proteoglycan. As displayed in fig. 5A, $\mathrm{KCP}$ binds to heparan sulfate but not to chondroitin sulfate A. To compare the KCP binding to heparin and heparan sulfate, biotinylated proteoglycans were used (fig. 5B). In this system, KCP bound to heparin 2-fold stronger than to heparan sulfate.

\section{$3.5 \mathrm{KCP}$ binds to cell surface glycosaminoglycans via the heparin binding site}

To assess whether KCP can bind also to proteoglycans at the surface of cells. FITC-labelled $\mathrm{KCP}$ was incubated with $\mathrm{CHO}$ cells, followed by flow cytometric analysis. Figure 6A shows that wild type KCP bound to CHO-K1 cells in a dose dependent fashion. However, KCP mutant Lys64Gln/Lys65Gln/Lys88Gln, that was defective in heparin binding, was not capable of binding to the cell surface. Also, KCP could not bind to CHO pgsA-745, which are deficient in xylosyltransferase and therefore do not produce glycosaminoglycans (Esko et al., 1985). The cell surface binding of $\mathrm{KCP}$ was ionic in nature, as shown by fig. 6B, where KCP was allowed to bind to $\mathrm{CHO}$ cells at various concentrations of $\mathrm{NaCl}$. The binding decreased as a function of increasing $\mathrm{NaCl}$ concentrations and was barely detectable by this technique at physiological ionic strength, demonstrating that the KCP-cell surface binding was weak. To further characterize the cell surface binding site, $\mathrm{KCP}$-cell incubation was performed in the presence of heparin. As shown in fig. 6C, heparin completely inhibited the cell surface binding at $0.1 \mathrm{mg} / \mathrm{ml}$. Altogether, these data suggest that KCP binds to heparan sulfate at the surface of CHO-cells, via the binding site localized in CCP1-2.

\section{Discussion}

In this study, we demonstrate the heparin binding of KCP by its retention on a heparin column. The point mutants Arg20Gln/Arg33Gln/Arg35Gln and Lys64Gln/Lys65Gln/Lys88Gln did not bind to heparin, which localizes the heparin binding site to CCP1, stretching in to CCP2. Heparin binding to CCP1 was also observed in (Mullick et al., 2005). Single point mutations were not as defective in heparin binding as the corresponding triple mutant, indicating that the interaction is dependent on several bonds between the heparin molecule and different amino acids in KCP, which agrees well with what has been observed for most other heparin-protein interactions (Capila and Linhardt, 2002). Furthermore, the positively charged patches at more Cterminal parts of the protein, composed of residues Lys131, Lys133, His135 or Arg136, Lys138 or His158, His171, His213 were not required for heparin binding, indicating that the localized heparin binding site in CCP1-2 is not just binding as an effect of its net charge, but a specific 
binding site, also dependent on the surface complementarity between KCP and heparin. Also, a $\mathrm{KCP}$ construct devoid of CCP4 could bind to heparin equally as well as wild type KCP, demonstrating that CCP4 is not involved in heparin binding as opposed to VCP, which has a heparin binding site in CCP4 (Ganesh et al., 2004).

Heparin binding to KCP was also studied by docking simulations. Since experimental results indicated a binding site in CCP1-2 and since CCP 4 was not involved in heparin binding, we decided to limit the search for a binding site to the CCP domains 1 and 2 . The docking simulations that yielded the results presented here were performed without previous knowledge of the critical residues found experimentally using point mutants. The first finding when analyzing the simulation results was that the heparin molecule was consistently positioned on or nearby the positive patch located on the inter-domain region between CCP 1 and 2, especially in the extended conformation of KCP. It is interesting to note that the heparin pose agreeing with our experimental results was the most visited during the Monte-Carlo simulations. This indicates that an important energy minimum can be found in this positive patch. Interestingly, results of the docking simulations suggest that Arg20 does not make hydrogen bonds with heparin (thus this residue is not mentioned in Table 1). However, this residue is still at an appropriate distance to attract heparin via long-range Coulombic interaction.

With these reliable simulation data, we could start examining the probable role played by the different CCP1 and 2 angles. In the extended conformation, a large positively charged platform is exposed to the solvent, thus facilitating the docking of the heparin molecule. Alternatively, in the bent conformation, the disposition of the critical amino acids on a smaller area seems to present a less favourable docking site. Moreover, the difference in the orientation of CCP 1 and 2 domains is not restricted to the angle formed between them, but also the rotation along the longer axis of the CCP1 in respect to CCP2. As a consequence, the twist necessary for the heparin molecule to embrace all the implicated residues is more significant when binding to the bent conformation, resulting in higher torsional energy and is limited by internal steric impediments of the heparin molecule itself.

Furthermore, the formation of a strong positive patch in the bent conformation would require the participation of additional amino acids located at the inter-domain linker of CCP2-3 of KCP (Lys131, Lys133, His135, Arg136 and Lys138) as can be seen in figure 3B. However, the contribution of these amino acids to heparin binding can be ruled out, as suggested by our site directed mutagenesis experiments.

One of the critical amino acids - Lys65- is conserved in CR1 and DAF, both in structure and sequence. In all three cases, this conserved lysine is interacting with a beta-hairpin positioned in the inter-domain region of CCP1 and 2 (Fig. 3C, inset). The prodding conformation adopted by this beta-hairpin limits the swinging motion of the CCP domains involved and is further stabilized by the conserved Lys65, suggesting that extended conformation is adopted and maintained for at least part of the time. With limited inter-domain motion a stable positive patch can be formed and sustained. Approaching heparin molecules in solution can therefore bind with only small torsional changes on its stable conformation, which is consistent with previous observations of experimental heparin structures (PDB code 1hpn) or co-crystallysed complexes (eg. PDB codes 1rid, 1bfc and 1e0o) (Faham et al., 1996; Ganesh et al., 2004; Mulloy et al., 1993; Pellegrini et al., 2000).

We observed that KCP binds to the surface of CHO cells by the heparin binding site. Even though $\mathrm{CHO}$ cells are not the natural target for KSHV, this cell line is a good model for studying viral proteins involved in cell binding, since it has been shown that KSHV particles can both bind to and infect this kind of cells (Akula et al., 2001a; Bechtel et al., 2003). CHO cells were also chosen for the cell surface binding assays in order to take advantage of the CHO derivative pgsA-745 that do not produce glycosaminoglycans. KCP did not bind to pgsA-745 cells, which strongly suggests that glycosaminoglycans are the compound that KCP interacts 
with on the $\mathrm{CHO}$ cells. This finding is interesting, given the fact that KSHV binds to heparan sulfate during its attachment to its target cells (Akula et al., 2001b; Birkmann et al., 2001). So far, gpK8.1 and gB have been identified as the heparan sulfate binding ligands on KSHV (Akula et al., 2001a; Birkmann et al., 2001; Wang et al., 2001). However, it has also been shown that gpK8.1 is not required for KSHV entry into 293 cells (Luna et al., 2004). Based on our results, it can be speculated that KCP at the surface of KSHV particles aids the initial attachment of virus to target cells by binding to glycosaminoglycans. Albeit low affinity of KCP to cell surface (at physiological ionic strength the binding of recombinant $\mathrm{KCP}$ to $\mathrm{CHO}$ cells is marginal) this might be compensated for by higher avidity due to numerous copies of KCP at the virus surface. The heparin/heparan sulfate binding site is located at the two most N-terminal CCP domains and should thus be accessible for interaction with molecules in the area around the virus. We hypothesize the main function of KCP is to inhibit complement when expressed on the surface of infected cells and budding virus. However, once the viral particles reach a target cell and attempt to establish binding, KCP could be acting as an accessory receptor due to its ability to interact with heparan sulfate. The viral RCA homologue VCP, encoded by vaccinia virus, consists of four CCP domains and is very similar in structure to KCP with the exception that VCP is secreted and exists in a soluble form. VCP also binds to heparin and cell surfaces. Different studies have located the heparin binding to either both CCP 1-2 and 3-4 (Smith et al., 2000) or only CCP 3-4 (Smith et al., 2003). In the recently solved structure of VCP in complex with heparin, K214, K216, K220 and R244 in CCP 4 of VCP make up the key electrostatic interactions (Ganesh et al., 2004). Thus, despite the structural and functional similarity of KCP and VCP, they seem to utilize opposite ends for heparin binding. This might reflect the different nature of VCP and KCP, with respect to that VCP is secreted while KCP is attached to the membrane. In a model of VCP function, it was proposed that VCP binds to the surface of cells in the vicinity of vaccinia virus infected cells via its C-terminal end, while it is simultaneously capable of complement down regulation by a putative functional site in CCP1-2 (Smith et al., 2003). It appears that VCP binds heparin more strongly than KCP: in a study by Smith et al (Smith et al., 2000), VCP binding to heparin was investigated using affinity chromatography. In such a setup, VCP elutes at around $500 \mathrm{mM} \mathrm{NaCl}$, while KCP eluted in the present study at around $200 \mathrm{mM} \mathrm{NaCl}$.

The heparin binding site in KCP is very similar to the site in the human complement regulator C4BP, where it encompasses amino acids Arg39, Lys64 and Lys66 (Blom et al., 1999). They are exposed at the tip of the CCP1-2 angle (of totally eight CCP domains), similar to Lys64, Lys65 and Lys88 in KCP. Factor H has several heparin binding sites dispersed over its 20 CCP domains (Blackmore et al., 1998; Blackmore et al., 1996; Pangburn et al., 1991; Ram et al., 1998) that localize factor $H$ to the surface of endogenous cells, making it efficiently discriminate between self and non-self tissue for complement inactivation. It appears as the site located in CCP19-20 is the one that is responsible for binding to self cells. (Pangburn, 2002). Interestingly, for several cases of atypical haemolytic uremic syndrome, mutations have been identified in this $\mathrm{C}$-terminal end of factor $\mathrm{H}$, and some of those have been experimentally shown to decrease factor $\mathrm{H}$ binding to heparin and endothelial cells (Manuelian et al., 2003). This illustrates the importance of the heparin binding for an RCA.

To summarize this study; we here show that the viral complement inhibitor KCP can bind to heparin, similarly to other human and viral complement regulators. The heparin binding site was explored by site directed mutagenesis and molecular docking, and we could define a positively charged area in CCP1-2 as the heparin binding site. Taken together, these data allow us to propose a reliable 3D model of the KCP-heparin complex. We also show that KCP binds to heparan sulfate at the surface of $\mathrm{CHO}$ cells, which might contribute to KSHV attachment to its target cells. Hence, the present report might add to the knowledge about KSHV biology as well as protein-heparin interaction in general. 


\section{Acknowledgements}

The authors would like to thank prof Dick Heinegård, Lund University who generously provided CHO-K1 and pgsA-745 cells.

This study was supported by was supported by Cancerfonden, The Swedish Foundation for Strategic Research, Swedish Research Council, Foundations of Österlund, Kock, Crafoord, Jan and Inga Hain, Zoega, Svartz, Bergvalls, Påhlsson, King Gustav V's 80th Anniversary Foundation, American Cancer Foundation and research grants from the University Hospital in Malmö (to AB) as well as INSERM (to BV and WHL).

\section{References}

Akula S. M., Naranatt P. P., Walia N. S., Wang F. Z., Fegley B. and Chandran B. (2003) Kaposi's sarcomaassociated herpesvirus (human herpesvirus 8) infection of human fibroblast cells occurs through endocytosis. J Virol 77, 7978-90.

Akula S. M., Pramod N. P., Wang F. Z. and Chandran B. (2001a) Human herpesvirus 8 envelope-associated glycoprotein B interacts with heparan sulfate-like moieties. Virology 284, 235-49.

Akula S. M., Pramod N. P., Wang F. Z. and Chandran B. (2002) Integrin alpha3beta1 (CD 49c/29) is a cellular receptor for Kaposi's sarcoma-associated herpesvirus (KSHV/HHV-8) entry into the target cells. Cell 108, 407-19.

Akula S. M., Wang F. Z., Vieira J. and Chandran B. (2001b) Human herpesvirus 8 interaction with target cells involves heparan sulfate. Virology 282, 245-55.

Andersson M., Hanson A., Englund G. and Dahlback B. (1991) Inhibition of complement components C3 and C4 by cadralazine and its active metabolite. Eur J Clin Pharmacol 40, 261-5.

Bechtel J. T., Liang Y., Hvidding J. and Ganem D. (2003) Host range of Kaposi's sarcoma-associated herpesvirus in cultured cells. $J$ Virol 77, 6474-81.

Birkmann A., Mahr K., Ensser A., Yaguboglu S., Titgemeyer F., Fleckenstein B. and Neipel F. (2001) Cell surface heparan sulfate is a receptor for human herpesvirus 8 and interacts with envelope glycoprotein K8.1. $J$ Virol 75, 11583-93.

Blackmore T. K., Hellwage J., Sadlon T. A., Higgs N., Zipfel P. F., Ward H. M. and Gordon D. L. (1998) Identification of the second heparin-binding domain in human complement factor H. J Immunol 160, 3342-8.

Blackmore T. K., Sadlon T. A., Ward H. M., Lublin D. M. and Gordon D. L. (1996) Identification of a heparin binding domain in the seventh short consensus repeat of complement factor H. J Immunol 157, 5422-7.

Blom A. M., Webb J., Villoutreix B. O. and Dahlback B. (1999) A cluster of positively charged amino acids in the C4BP alpha-chain is crucial for C4b binding and factor I cofactor function. J Biol Chem 274, 19237-45.

Boshoff C., Schulz T. F., Kennedy M. M., Graham A. K., Fisher C., Thomas A., McGee J. O., Weiss R. A. and O'Leary J. J. (1995) Kaposi's sarcoma-associated herpesvirus infects endothelial and spindle cells. Nat Med 1, 1274-8.

Brive L. and Abagyan R. (2002) Computational structural proteomics. Ernst Schering Res Found Workshop, 14966.

Capila I. and Linhardt R. J. (2002) Heparin-protein interactions. Angew Chem Int Ed Engl 41, 391-412.

Cerimele F., Curreli F., Ely S., Friedman-Kien A. E., Cesarman E. and Flore O. (2001) Kaposi's sarcoma-associated herpesvirus can productively infect primary human keratinocytes and alter their growth properties. $J$ Virol 75, 2435-43.

Cesarman E., Chang Y., Moore P. S., Said J. W. and Knowles D. M. (1995) Kaposi's sarcoma-associated herpesvirus-like DNA sequences in AIDS- related body-cavity-based lymphomas. N Engl J Med 332, 1186-91.

Chang Y., Cesarman E. and Pessin M. (1994) Identification of herpesvirus-like DNA sequences in AIDS-associated Kaposi's sarcoma. Science, 1865-9.

Crossley L. G. and Porter R. R. (1980) Purification of the human complement control protein C3b inactivator. Biochem J 191, 173-82.

Esko J. D., Stewart T. E. and Taylor W. H. (1985) Animal cell mutants defective in glycosaminoglycan biosynthesis. Proc Natl Acad Sci U S A 82, 3197-201.

Faham S., Hileman R. E., Fromm J. R., Linhardt R. J. and Rees D. C. (1996) Heparin structure and interactions with basic fibroblast growth factor. Science 271, 1116-20.

Fernandez-Recio J., Totrov M. and Abagyan R. (2002) Soft protein-protein docking in internal coordinates. Protein Sci 11, 280-91. 
Fernandez-Recio J., Totrov M. and Abagyan R. (2003) ICM-DISCO docking by global energy optimization with fully flexible side-chains. Proteins 52, 113-7.

Foreman K. E., Bacon P. E., Hsi E. D. and Nickoloff B. J. (1997) In situ polymerase chain reaction-based localization studies support role of human herpesvirus- 8 as the cause of two AIDS-related neoplasms: Kaposi's sarcoma and body cavity lymphoma. J Clin Invest 99, 2971-8.

Ganesh V. K., Smith S. A., Kotwal G. J. and Murthy K. H. (2004) Structure of vaccinia complement protein in complex with heparin and potential implications for complement regulation. Proc Natl Acad Sci U S A 101, 8924-9.

Greenwood F. C., Hunter W. M. and Glover J. S. (1963) The Preparation of I-131-Labelled Human Growth Hormone of High Specific Radioactivity. Biochem J 89, 114-23.

Harris C. L., Spiller O. B. and Morgan B. P. (2000) Human and rodent decay-accelerating factors (CD55) are not species restricted in their complement-inhibiting activities. Immunology 100, 462-70.

Jenner R. G., Alba M. M., Boshoff C. and Kellam P. (2001) Kaposi's sarcoma-associated herpesvirus latent and lytic gene expression as revealed by DNA arrays. J Virol 75, 891-902.

Lukacik P., Roversi P., White J., Esser D., Smith G. P., Billington J., Williams P. A., Rudd P. M., Wormald M. R., Harvey D. J., Crispin M. D., Radcliffe C. M., Dwek R. A., Evans D. J., Morgan B. P., Smith R. A. and Lea S. M. (2004) Complement regulation at the molecular level: the structure of decay-accelerating factor. Proc Natl Acad Sci U S A 101, 1279-84.

Luna R. E., Zhou F., Baghian A., Chouljenko V., Forghani B., Gao S. J. and Kousoulas K. G. (2004) Kaposi's sarcoma-associated herpesvirus glycoprotein K8.1 is dispensable for virus entry. J Virol 78, 6389-98.

Manuelian T., Hellwage J., Meri S., Caprioli J., Noris M., Heinen S., Jozsi M., Neumann H. P., Remuzzi G. and Zipfel P. F. (2003) Mutations in factor H reduce binding affinity to C3b and heparin and surface attachment to endothelial cells in hemolytic uremic syndrome. J Clin Invest 111, 1181-90.

Mark L., Lee W. H., Spiller O. B., Proctor D., Blackbourn D. J., Villoutreix B. O. and Blom A. M. (2004) The Kaposi's Sarcoma-associated Herpesvirus Complement Control Protein Mimics Human Molecular Mechanisms for Inhibition of the Complement System. J Biol Chem 279, 45093-101.

Monini P., Colombini S., Sturzl M., Goletti D., Cafaro A., Sgadari C., Butto S., Franco M., Leone P., Fais S., Melucci-Vigo G., Chiozzini C., Carlini F., Ascherl G., Cornali E., Zietz C., Ramazzotti E., Ensoli F., Andreoni M., Pezzotti P., Rezza G., Yarchoan R., Gallo R. C. and Ensoli B. (1999) Reactivation and persistence of human herpesvirus- 8 infection in B cells and monocytes by Th-1 cytokines increased in Kaposi's sarcoma. Blood 93, 4044-58.

Mullick J., Bernet J., Singh A. K., Lambris J. D. and Sahu A. (2003) Kaposi's sarcoma-associated herpesvirus (human herpesvirus 8) open reading frame 4 protein (kaposica) is a functional homolog of complement control proteins. J Virol 77, 3878-81.

Mullick J., Singh A. K., Panse Y., Yadav V., Bernet J. and Sahu A. (2005) Identification of Functional Domains in Kaposica, the Complement Control Protein Homolog of Kaposi's Sarcoma-Associated Herpesvirus (Human Herpesvirus 8). J Virol 79, 5850-6.

Mulloy B., Forster M. J., Jones C. and Davies D. B. (1993) N.m.r. and molecular-modelling studies of the solution conformation of heparin. Biochem J 293 ( Pt 3), 849-58.

Murthy K. H., Smith S. A., Ganesh V. K., Judge K. W., Mullin N., Barlow P. N., Ogata C. M. and Kotwal G. J. (2001) Crystal structure of a complement control protein that regulates both pathways of complement activation and binds heparan sulfate proteoglycans. Cell 104, 301-11.

Naranatt P. P., Akula S. M., Zien C. A., Krishnan H. H. and Chandran B. (2003) Kaposi's sarcoma-associated herpesvirus induces the phosphatidylinositol 3-kinase-PKC-zeta-MEK-ERK signaling pathway in target cells early during infection: implications for infectivity. $J$ Virol 77, 1524-39.

Pangburn M. K. (2002) Cutting edge: localization of the host recognition functions of complement factor $\mathrm{H}$ at the carboxyl-terminal: implications for hemolytic uremic syndrome. J Immunol 169, 4702-6.

Pangburn M. K., Atkinson M. A. and Meri S. (1991) Localization of the heparin-binding site on complement factor H. J Biol Chem 266, 16847-53.

Panyutich E. A., Said J. W. and Miles S. A. (1998) Infection of primary dermal microvascular endothelial cells by Kaposi's sarcoma-associated herpesvirus. Aids 12, 467-72.

Pellegrini L., Burke D. F., von Delft F., Mulloy B. and Blundell T. L. (2000) Crystal structure of fibroblast growth factor receptor ectodomain bound to ligand and heparin. Nature 407, 1029-34.

Ram S., Sharma A. K., Simpson S. D., Gulati S., McQuillen D. P., Pangburn M. K. and Rice P. A. (1998) A novel sialic acid binding site on factor $\mathrm{H}$ mediates serum resistance of sialylated Neisseria gonorrhoeae. $J$ Exp Med 187, 743-52.

Shukla D. and Spear P. G. (2001) Herpesviruses and heparan sulfate: an intimate relationship in aid of viral entry. $J$ Clin Invest 108, 503-10. 
Smith B. O., Mallin R. L., Krych-Goldberg M., Wang X., Hauhart R. E., Bromek K., Uhrin D., Atkinson J. P. and Barlow P. N. (2002) Structure of the C3b binding site of CR1 (CD35), the immune adherence receptor. Cell 108, 769-80.

Smith S. A., Mullin N. P., Parkinson J., Shchelkunov S. N., Totmenin A. V., Loparev V. N., Srisatjaluk R., Reynolds D. N., Keeling K. L., Justus D. E., Barlow P. N. and Kotwal G. J. (2000) Conserved surfaceexposed K/R-X-K/R motifs and net positive charge on poxvirus complement control proteins serve as putative heparin binding sites and contribute to inhibition of molecular interactions with human endothelial cells: a novel mechanism for evasion of host defense. J Virol 74, 5659-66.

Smith S. A., Sreenivasan R., Krishnasamy G., Judge K. W., Murthy K. H., Arjunwadkar S. J., Pugh D. R. and Kotwal G. J. (2003) Mapping of regions within the vaccinia virus complement control protein involved in dose-dependent binding to key complement components and heparin using surface plasmon resonance. Biochim Biophys Acta 1650, 30-9.

Soulier J., Grollet L., Oksenhendler E., Cacoub P., Cazals-Hatem D., Babinet P., d'Agay M. F., Clauvel J. P., Raphael M., Degos L. and et al. (1995) Kaposi's sarcoma-associated herpesvirus-like DNA sequences in multicentric Castleman's disease. Blood 86, 1276-80.

Spear P. G. and Longnecker R. (2003) Herpesvirus entry: an update. J Virol 77, 10179-85.

Spiller O. B. (2003) Functional Activity of the Complement Regulator Encoded by Kaposi's Sarcoma-associated Herpesvirus. The Journal of Biological Chemistry 278, 9283-9289.

Spiller O. B., Robinson M., O'Donnell E., Milligan S., Morgan B. P., Davison A. J. and Blackbourn D. J. (2003) Complement regulation by Kaposi's sarcoma-associated herpesvirus ORF4 protein. J Virol 77, 592-9.

Totrov M. and Abagyan R. (1997) Flexible protein-ligand docking by global energy optimization in internal coordinates. Proteins Suppl 1, 215-20.

Totrov M. M. A., R. (2001) $R V$.

Vieira J., O'Hearn P., Kimball L., Chandran B. and Corey L. (2001) Activation of Kaposi's sarcoma-associated herpesvirus (human herpesvirus 8) lytic replication by human cytomegalovirus. $J$ Virol 75, 1378-86.

Wang F. Z., Akula S. M., Pramod N. P., Zeng L. and Chandran B. (2001) Human herpesvirus 8 envelope glycoprotein K8.1A interaction with the target cells involves heparan sulfate. J Virol 75, 7517-27. 


\section{Figure legends}

Fig. 1. Analysis of purified recombinant KCP proteins. Wild type or mutated KCP was analysed by separation by SDS-PAGE on $12 \%$ gel under reducing conditions, followed by Coomassie staining.

Fig. 2. KCP binds to heparin via a positively charged patch in CCP 1-2. KCP was loaded on a Heparin column equilibrated with $20 \mathrm{mM}$ Tris, $\mathrm{pH}$ 7.35. Bound $\mathrm{KCP}$ was eluted by a salt gradient, ranging from 0-500 $\mathrm{mM} \mathrm{NaCl}$. Eluted $\mathrm{KCP}$ was detected by measuring the absorbance at $214 \mathrm{~nm}$ and the $\mathrm{NaCl}$ concentration at the peak of elution is indicated. (A) Wild type $\mathrm{KCP}$ bound to heparin and eluted at $209 \mathrm{mM} \mathrm{NaCl}$. (B) KCP mutant Arg20Gln/Arg33Gln/Arg35Gln did not bind to the heparin column, and eluates at $0 \mathrm{mM} \mathrm{NaCl}$. (C) The heparin binding of $\mathrm{KCP}$ mutant Lys64Gln/Lys65Gln/Lys88Gln was severely defective. (D-F) KCP mutants Lys131Gln/Lys133Gln/His135Gln, Arg136Gln/Lys138Gln and His158Ala/His171Ala/His213Ala bound to the heparin column with the same affinity as wild type KCP. The experiment was reproducibly repeated at least two independent occasions. Not shown in the figure are the elution peaks for monomeric KCP (181 mM NaCl), KCP K64Q (192 $\mathrm{mM} \mathrm{NaCl}), \mathrm{K} 65 \mathrm{Q}(127 \mathrm{mM} \mathrm{NaCl}), \mathrm{KCP} \mathrm{K} 88 \mathrm{Q}(201 \mathrm{mM} \mathrm{NaCl})$ and KCP delCCP4 (237 mM $\mathrm{NaCl})$.

Fig. 3. Heparin docking results. (A) KCP models are shown as ribbons (red:bent, green: extended) and heparin molecules are shown as solid van der Waals surfaces (red: best docking solution on bent KCP, green: best docking solution on extended KCP). The, for heparin binding, critical residues (as found by point mutants) are shown as blue sticks. The limit between CCP1 and 2 is shown as a black horizontal line. (B) Electrostatic potential distribution on the surface of KCP models in extended (left) and bent (right) conformations. The view on the bottom row is rotated $\sim 120$ degrees on the $\mathrm{Y}$-axis in respect to the top row showing that the strongest positively charged patch occurs in different faces of KCP depending on the conformation adopted by CCP1-2. (C) Detailed view of the heparin (magenta sticks) docked on the extended conformation of KCP. The residues found to be critical to binding through mutational studies presented here are shown in blue balls-and-sticks representation. Additional residues involved in the binding as predicted by docking are shown as green sticks. White-grey dots represent hydrogen bonds. Ribbons representation of KCP main chain is shown in dark green. Betahairpin is highlighted in yellow and the carbonyl of the residue (Ile114) interacting with the conserved Lys65 is shown as green stick. Inset (right): Conserved residues interacting with the beta-hairpin. Superimposed ribbons representations of the extended KCP model (green), DAF (cyan) and CR1 (blue) and its corresponding conserved lysines (KCP: Lys65; DAF: Lys129; CR1; Lys961).

Fig. 4. Heparin inhibits KCP cofactor function. Factor I (60 nM), KCP (300 nM) and C4b (125 $\mathrm{nM})$ or $\mathrm{C} 3 \mathrm{~b}(375 \mathrm{nM})$ plus trace amounts of ${ }^{125} \mathrm{I}$ labeled $\mathrm{C} 4 \mathrm{~b}$ or $\mathrm{C} 3 \mathrm{~b}$ respectively, were incubated at physiological saline conditions at $37^{\circ} \mathrm{C}$ for $90 \mathrm{~min}$ at various concentrations of Heparin, as indicated in the figure. The proteins were separated by $10-15 \%$ gradient SDS/PAGE under reducing conditions. The cleavage products were visualized by autoradiography. KCP cofactor activity leads to factor I cleavage of the $\mathrm{C} 3 \mathrm{~b}$ and $\mathrm{C} 4 \mathrm{~b} \alpha$-chains and formation of the $\mathrm{C} 3$ 64- 46- and $43 \mathrm{kDa}$ products and $\mathrm{C} 4 \mathrm{~d}$, for $\mathrm{C} 3 \mathrm{~b}$ and $\mathrm{C} 4 \mathrm{~b}$, respectively. The cofactor function was evaluated by measuring the optical density of the $\mathrm{C} 4 \mathrm{~d}$ and $64 \mathrm{kDa}$ cleavage products. The cleavage products formed without any Heparin was set as $100 \%$. As a negative control we used sample without added factor I (no fI). The experiment was repeated three times, and the mean value is presented in the graph. Error bars represent the standard deviation. 
Fig. 5. KCP binds to heparan sulfate. (A) Heparan sulfate and Chondroitin sulfate A were immobilized to micro titer wells. KCP was allowed to bind, in concentrations of 50 or 100 $\mu \mathrm{g} / \mathrm{ml}$, as indicated. The control shows the background binding of KCP to wells that were coated with only coating buffer, then treated as the other wells. (B) Biotinylated heparin and heparan sulfate was added to streptavidin coated micro titer wells, then KCP was added, and the experiment was performed as in A. For the controls, no proteoglycan was added to the wells. The experiment was carried out at $75 \mathrm{mM} \mathrm{NaCl}$ concentration. The error bars represent the standard deviation.

Fig. 6. KCP binds to glycosaminoglycans at the surface of $\mathrm{CHO}$ cells. FITC labelled, wild type (wt) KCP and mutant Lys64Gln/Lys65Gln/Lys88Gln (K64Q/K65Q/K88Q) were incubated with $\mathrm{CHO}$ cells and KCP binding was evaluated by flow cytometry. $\mathrm{CHO}$ pgsA-745 is a derivative of $\mathrm{CHO}-\mathrm{K} 1$, and do not produce glycosaminoglycans. (A) $\mathrm{CHO}$ cells were incubated with various concentrations of KCP at low ionic strength. (B) CHO-K1 cells were incubated with KCP (200 $\mu \mathrm{g} / \mathrm{ml}$ ) at various concentration of $\mathrm{NaCl}$. (C) $\mathrm{CHO}-\mathrm{K} 1$ cells were incubated with wild type $\mathrm{KCP}$ $(200 \mu \mathrm{g} / \mathrm{ml})$ and various concentrations of heparin (column 1-5). Column 6 is CHO-K1 cells together with KCP mutant Lys64Gln/Lys65Gln/Lys88Gln and column 7 is wild type KCP binding to $\mathrm{CHO}$ derivative pgsA-745. The experiments were repeated at three different occasions and $\mathrm{A}, \mathrm{B}$ and $\mathrm{C}$ were performed separately. The figures show the mean value of triplicates from one representative experiment for the various conditions. The error bars correspond to the standard deviation. 


\begin{tabular}{|l|l|}
\hline Extended CCP1-2 angle (19 H-bonds) & Bent CCP1-2 angle (19 H-bonds) \\
\hline Arg33 $(1.98,1.92)$ & Ser36 (1.91) \\
\hline Arg35 $(2.07,1.51,2.39,2.46,2.24)$ & Tyr38 $(1.94)$ \\
\hline Lys64 $(2.35,2.71)$ & Lys64 $(2.00,2.38,2.02,2.14,2.61,2.32$, \\
& $2.15,2.60)$ \\
\hline Lys65 $(2.01)$ & Lys65 $(1.74,2.33)$ \\
\hline Gln84 (1.92) & Asn69 $(1.99)$ \\
\hline Lys88 $(2.29,2.24,2.67,2.06,1.91)$ & Arg106 (2.40, 2.34, 2.75) \\
\hline Tyr89 $(2.30)$ & Arg110 (2.32) \\
\hline Gly90 (2.61,2.44) & Trp122 $(2.44)$ \\
\hline & Ser125 (2.78) \\
\hline
\end{tabular}

Table 1 Residues in KCP that form hydrogen bonds to the heparin molecule, as investigated with molecular docking simulations. Hydrogen bonding distances ( $\mathrm{H}$ to heavy atoms) from protein to heparin are presented in parentheses. Residues that are part of the positive patch critical for heparin binding are in bold.

\begin{tabular}{|ll|}
\hline $\begin{array}{l}\text { Heparin } \\
\text { concentration }\end{array}$ & $\mathrm{K}_{\mathrm{D}}$ \\
\hline $0 \mathrm{mg} / \mathrm{ml}$ & $32 \mathrm{nM}$ \\
$0.03 \mathrm{mg} / \mathrm{ml}$ & $29 \mathrm{nM}$ \\
$0.3 \mathrm{mg} / \mathrm{ml}$ & $256 \mathrm{nM}$ \\
$1.6 \mathrm{mg} / \mathrm{ml}$ & $8380 \mathrm{nM}$ \\
\hline
\end{tabular}

Table 2. Heparin decreases $\mathrm{C} 4 \mathrm{~b}$ binding to KCP. The interaction between $\mathrm{KCP}$ and $\mathrm{C} 4 \mathrm{~b}$ was analysed using the surface plasmon resonance technique (biacore). Dimeric KCP was immobilized on a CM5 sensorchip. Various concentrations of C4b, together with different concentrations of the low molecular weight heparin (fragmin) were injected over the chip. $\mathrm{K}_{\mathrm{D}}$ for $\mathrm{C} 4 \mathrm{~b}$ binding to $\mathrm{KCP}$ was calculated at the various concentrations of heparin. 


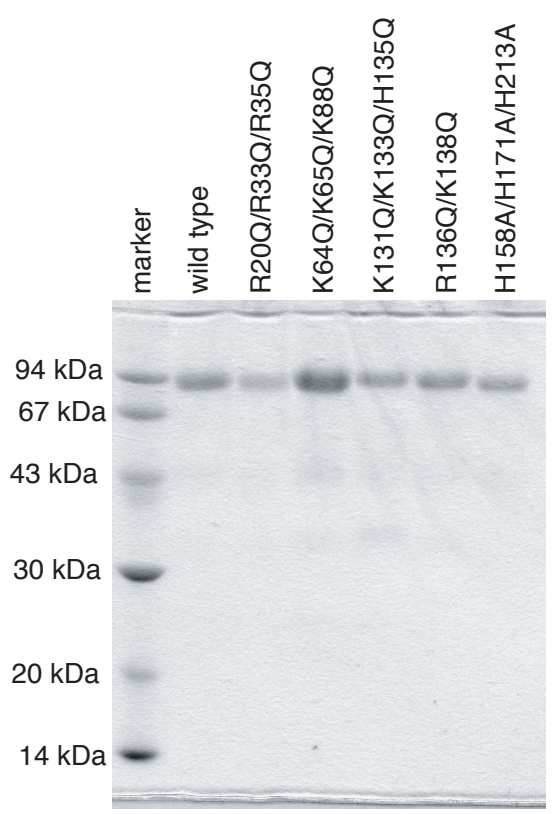

Fig 1 


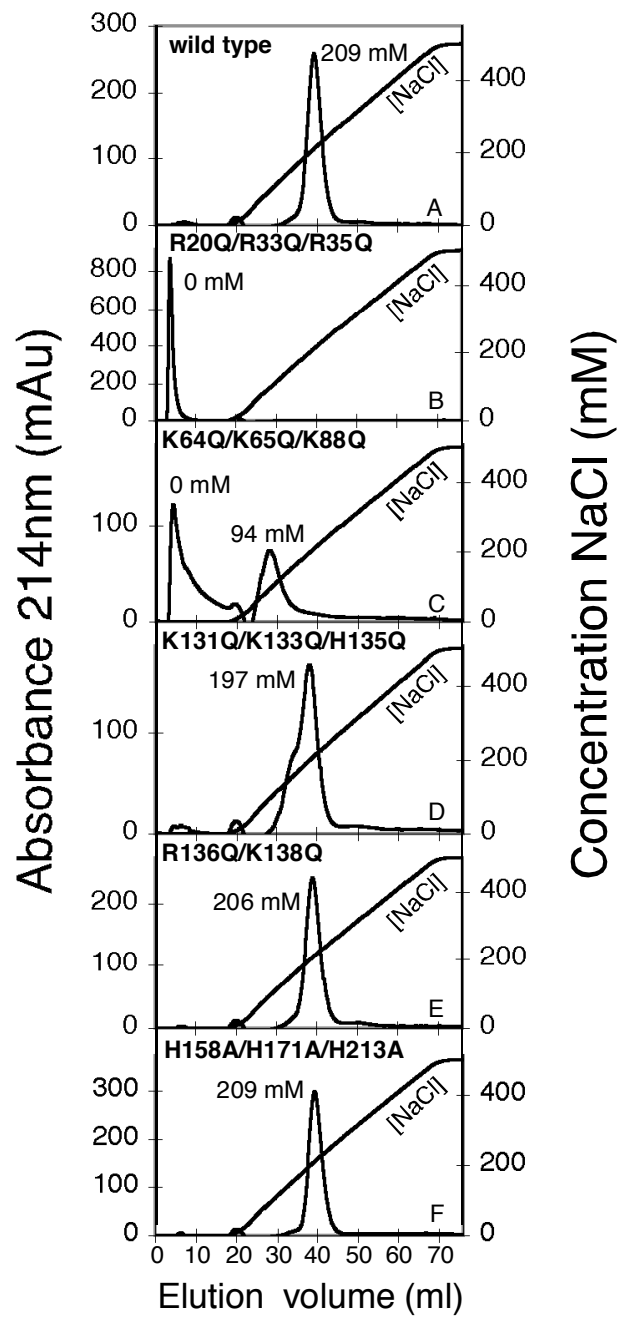

Fig 2 


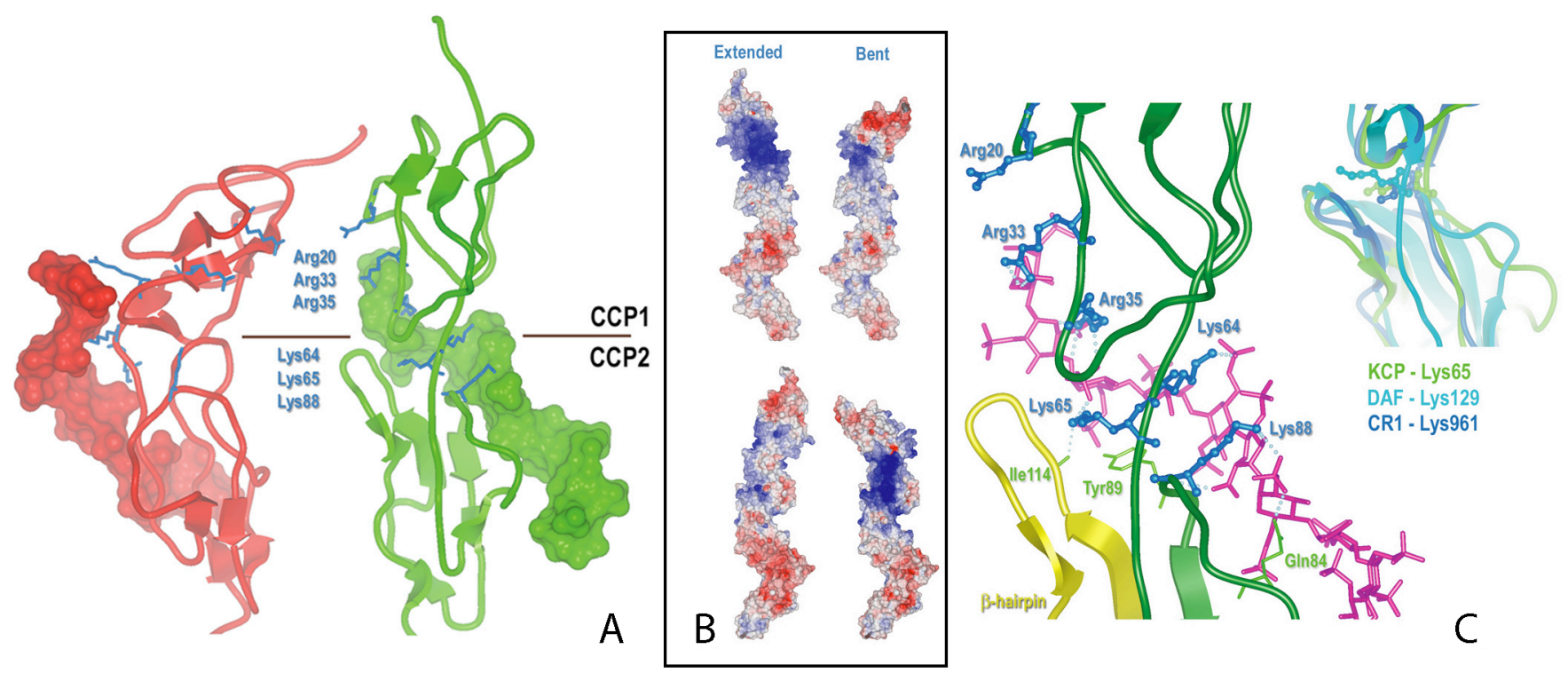

Fig3 
Fig 4

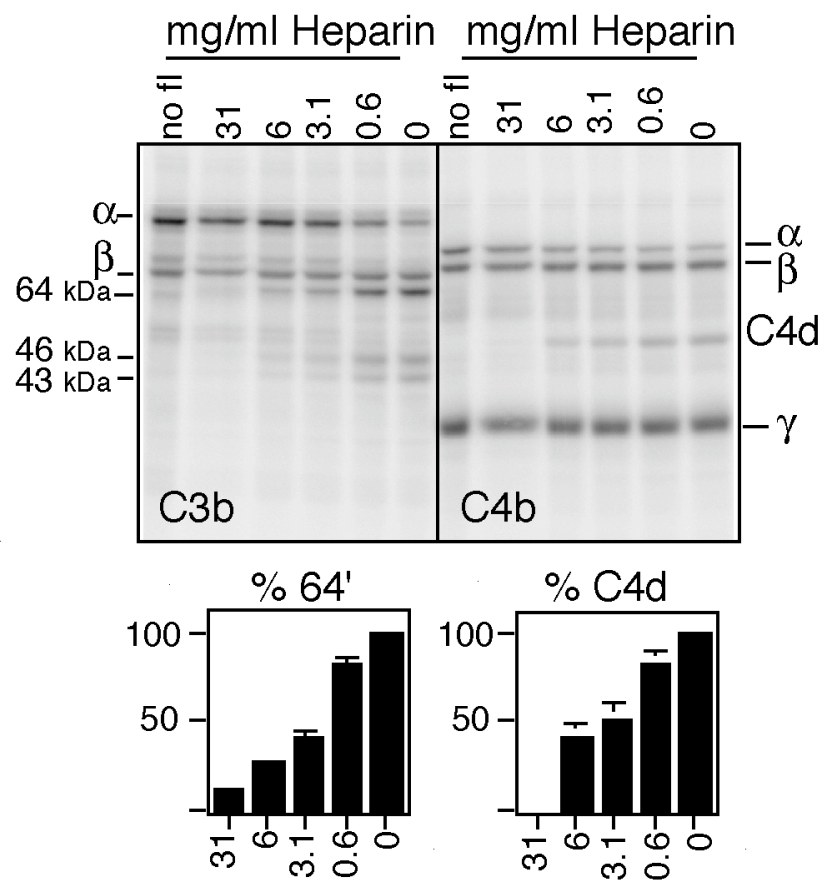

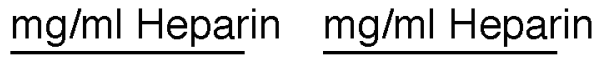




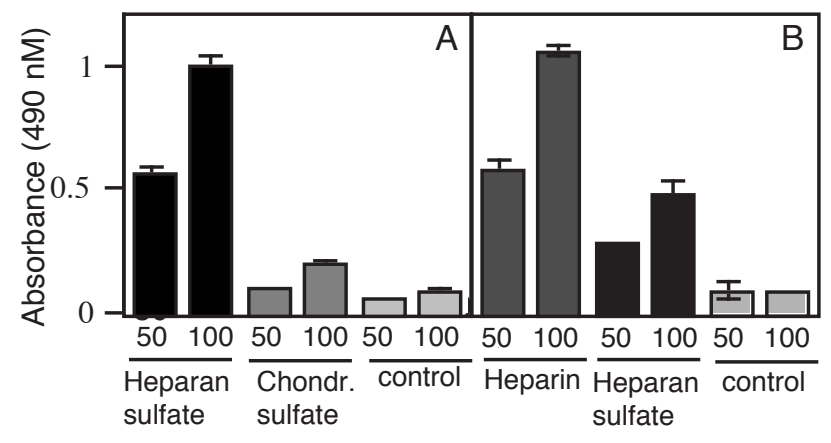

Fig5 

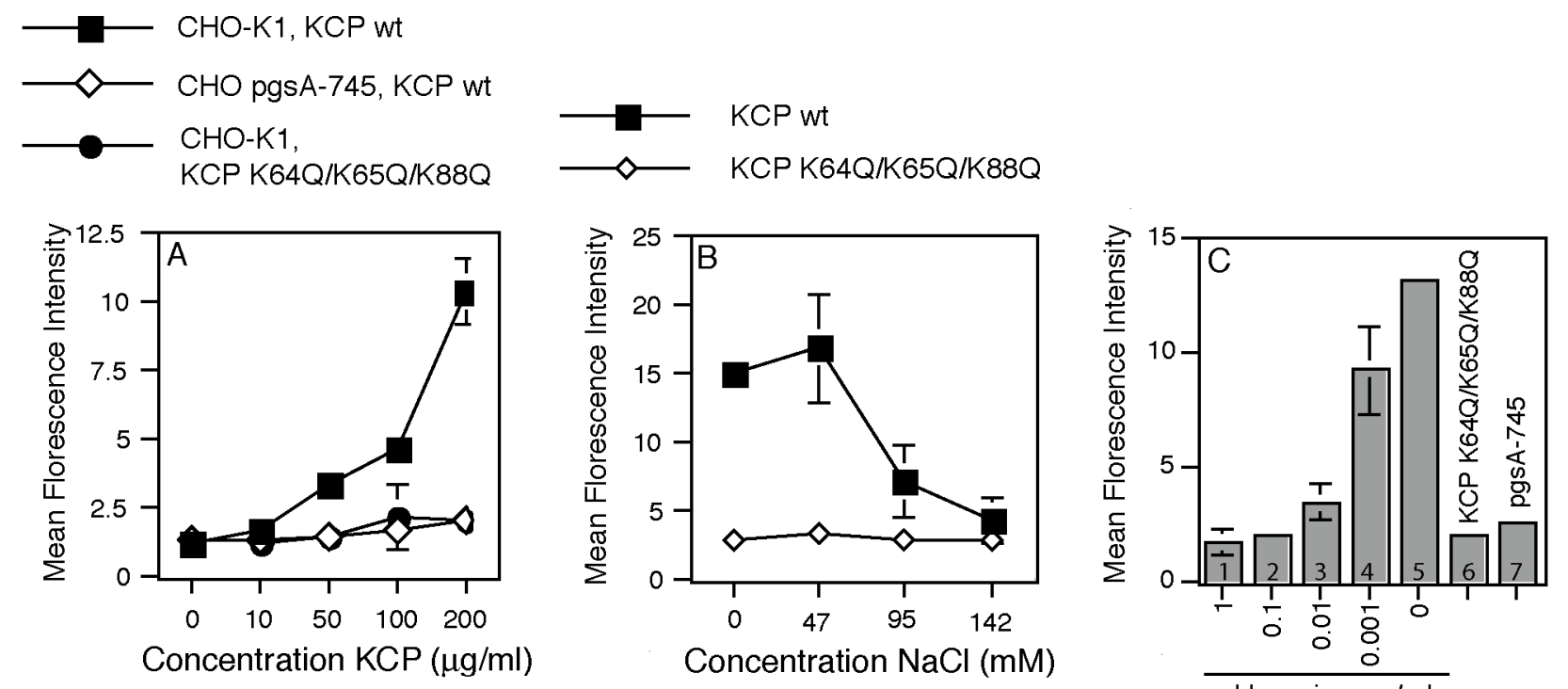

Heparin, mg/ml

CHO-K1

Fig 6 